\title{
The Effect of Methylparaben on Development and Fecundity of Drosophila melanogaster
}

\author{
Emel ATLI
}

Nevşehir Hacı Bektaş Veli University, Faculty of Education, Department of Mathematics and Science Education, Nevşehir, Turkey ORCID ID: Emel ATLI: https:/ / orcid.org/0000-0002-0220-546X

\begin{abstract}
Received: 05.11.2021
Accepted: 07.12 .2021

Published online: 10.12 .2021

Issue published: 31.12 .2021

Abstract: Parabens are a group of chemicals used as preservatives in many industrial products such as foods, cosmetics, and pharmaceuticals. Recent studies have revealed that these chemicals have endocrine disrupting properties. Drosophila melanogaster is one of the suitable model organisms used to test the toxic effect of various chemicals in vivo. In this study, the effects of methylparaben (MP) $(50 \mathrm{mM}, 100 \mathrm{mM}$, and $200 \mathrm{mM})$, one of the most commonly used parabens, on the developmental parameters and fecundity of $D$. melanogaster were examined. No significant difference was observed in the viability rates from larva to pupa and from pupa to adult. However, experimented MP concentrations caused a delay in larva to pupa and pupa to adult developmental times $(\mathrm{p}<0.05)$. While MP did not cause a significant change in mean offspring number, it significantly decreased fecundity at all doses $(\mathrm{p}<0.05)$.
\end{abstract}

Keywords: Paraben, endocrine disrupting compounds, developmental delay, offspring number, egg number.

\section{Metilparabenin Drosophila melanogaster'in Gelişimi ve Fekunditesi Üzerine Etkileri}

\begin{abstract}
Öz: Parabenler; gıdalar, kozmetik ürünler ve ilaçlar gibi birçok endüstriyel üründe koruyucu olarak kullanılan bir kimyasal madde grubudur. Son yıllarda yapılan çalışmalar, bu kimyasalların endokrin bozucu özelliği olduğunu ortaya koymuştur. Drosophila melanogaster çeşitli kimyasalların toksik etkisini in vivo olarak test etmek için kullanılan uygun model organizmalardan biridir. Bu çalışmada, en sık kullanılan parabenlerden biri olan metilparabenin (MP) (50 mM, $100 \mathrm{mM}$ ve 200 $\mathrm{mM})$ D. melanogaster'in gelişimi ve fekunditesi üzerine etkileri incelenmiştir. Pupalaşma ve erginleşme yüzdelerinde anlamlı bir fark gözlenmemiştir. Fakat MP uygulaması pupalaşma ve erginleşme sürelerinde gecikmeye yol açmıştır $(p<0.05)$. MP ortalama yavru döl sayısında anlamlı bir değişime yol açmazken, tüm dozlarda fekunditeyi önemli ölçüde azaltmıştır $(\mathrm{p}<0.05)$.
\end{abstract}

Anahtar kelimeler: Paraben, endokrin bozucular, gelişim zamanı gecikmesi, yavru döl sayısı, yumurta sayısı.

\section{Introduction}

In today's world, the increase in human population, the tendency to raise people's living standards, and rapid urbanization have increased the demand for ready-made foods and various cosmetic products. At this point, the use of protective additives has increased at the same rate. Parabens, which are para-hydroxybenzoic acid esters, are among the most widely used additives in the food, cosmetic, and pharmaceutical industries. The fact that it has a wide range of activity, low cost, and safe use for a long time has made these compounds very popular as antimicrobial protective additives (Soni et al., 2005). Parabens are also found in low concentrations in environmental samples such as rivers, air, and dust. Humans can be exposed to parabens through inhalation, oral ingestion, and dermal absorption (Chen et al., 2016). Methylparaben (MP), ethylparaben (EP), propylparaben (PP), and butylparaben (BP) are the most commonly used parabens (Soni et al., 2005).

Although they are thought to be safe, various toxicological and carcinogenic biological effects of parabens have been determined. Recent studies have shown that parabens can have endocrine disrupting effects and may be harmful to human health by showing weak estrogenic effects (Soni et al., 2005; Boberg et al., 2010). It has been determined that they can activate estrogen receptors (Era and $\operatorname{Er} \beta$ ) in human reporter cell lines (Gomez et al., 2005) and have an antagonistic relationship with human estrogen related receptor gamma (EERY) (Zhang et al., 2013). Moreover, the estrogenic effects of parabens have been detected in vivo by using a receptor binding assay and in vitro by using yeast-based estrogenic assay (Routledge et al., 1998). A decrease in sperm motility and fertility was also observed after paraben administrations (Tavares et al., 2009; Riad et al., 2018). Because of these properties, parabens have been classified by the Endocrine Society as potential endocrine disrupting chemicals (EDCs) (Chen et al., 2016).

Drosophila melanogaster is one of the most widely used organisms in biological studies due to its easy cultivation, the large number of offspring, small size, and well-known genetic characteristics (Li et al., 2015). In addition, it has been determined that this organism has similar toxin metabolic pathways with humans and vertebrates, and; therefore, it has been frequently used in toxicological studies (Gao et al., 2020). In the study investigating the effects of MP on growth, development, and egg production in D. melanogaster, it was determined that $2 \%$ MP concentration had a toxic effect, significantly reducing the number of eggs, larvae, pupae and eclosion and delaying the development time. In the same study, at a low concentration of $0.02 \%$, contrary to these results, it was 
observed that MP had potential estrogenic activity, increased the number of eggs, larvae, pupae and eclosion, and shortened the development time. (Gu et al., 2009). In a similar study, it was found that EP increased fertility at low concentrations $(0.02 \%)$ while it shortened lifespan and decreased fecundity at high concentrations $(0.10 \%, 0.20 \%)$. It was also determined that EP treatments changed the expression levels of estrogen-related receptor gene (ERR), ecdysone receptor gene (EcR), and yolk protein receptor gene (YPR) (Liu et al., 2014). In a study by Gao et al. (2020), it was determined that EP delayed the development of $D$. melanogaster and caused changes in hormone levels. In another study, Chen et al. (2016) investigated MP and EP mixture on lifespan and preadult development period in D. melanogaster and found that it reduced lifespan and affected preadult development.

In the present study, it was examined that the effects of MP on developmental parameters and fertility of $D$. melanogaster. Larva to pupa and pupa to adult viability rates, developmental times, mean offspring numbers, and mean egg numbers were determined. Thus, it is aimed to contribute to the literature on the effects of parabens, which we can take into our bodies with the foods we eat and the drugs and the cosmetic products we use. More research is needed to examine the potential additive toxicity of parabens.

\section{Material and Methods}

\subsection{Fly strains and media}

In the current study, the Canton S (CS) wild-type strain of Drosophila melanogaster was used as the model organism. The flies were reared on a standard cornmeal Drosophila medium. The stock cultures and experimental groups were kept in an incubator at $25 \pm 1^{\circ} \mathrm{C}$ temperature, with 50$60 \%$ humidity, and 12-h light and 12-h dark cycle.

\subsection{Chemicals and exposure procedure}

Methylparaben (MP) (99.0\% purity, CAS No. 99-76-3) was purchased from Sigma-Aldrich (Steinheim, Germany). All doses of MP were dissolved in $1 \mathrm{~mL}$ ethanol and completed to $1 \mathrm{~L}$ with $5 \%(\mathrm{w} / \mathrm{v})$ sucrose solution to prepare the stock solutions. The same volume of ethanol was added to the stock solution without MP as the control group.

The CS strain virgin females and males of the same age were mated in culture bottles. Parent flies were removed after $8 \mathrm{~h}$ and the third instar larvae were obtained $72 \pm 4 \mathrm{~h}$ later. These larvae were treated with $50 \mathrm{mM}, 100$ $\mathrm{mM}$, and $200 \mathrm{mM} \mathrm{MP}$ for $6 \mathrm{~h}$ in tubes containing drying papers that had absorbed $5 \mathrm{~mL}$ stock solutions.

Dose selection was made based on the results from previous studies. In studies performed by Ayar and Uysal (2013), the LD50 dose for MP was determined as $300 \mathrm{mM}$ in D. melanogaster. The doses used in this study $(50 \mathrm{mM}$, $100 \mathrm{mM}$, and $200 \mathrm{mM}$ ) were chosen lower than the determined LD50 dose. As these doses did not cause a lethal effect on the $D$. melanogaster larvae, the developmental and reproductive effects of this chemical could be examined.

\subsection{Pre-adult viability and developmental time assay}

The larvae of control and MP groups were placed in tubes that contained a standard cornmeal medium. There were ten tubes in each group and every tube contained ten larvae. Two repetitions were done for each group. The development of control and experimental groups was observed at $6-\mathrm{h}$ intervals. The number of individuals to reach pupal and adult stages and their developmental times were recorded separately. From the adults that emerged, virgin females were collected to use in "offspring number assay" experiment.

\subsection{Offspring number assay}

The virgin females hatched from treated larvae were used to examine the effects of MP on the average daily number of offspring. A female and 3 males collected from an untreated stock of the same age were mated. After the first pupa was seen, parents were removed. When the first adults hatched the number of emerged offsprings was counted at 24-h intervals for 10 days.

\subsection{Fecundity assay}

The CS strain third instar larvae of D. melanogaster were treated with $50 \mathrm{mM}, 100 \mathrm{mM}$, and $200 \mathrm{mM} \mathrm{MP}$ for $6 \mathrm{~h}$. Virgin females developed from the treated larvae were used to determine the effects of MP on fecundity. A female (treated) and three males (non-treated) of the same age (3 days old) were crossed in empty glass culture bottles. Then, plastic spoons containing standard cornmeal medium were placed in these culture bottles. These spoons were changed every $24-\mathrm{h}$ and the eggs laid in the spoons were counted with a stereomicroscope for 10 days.

\subsection{Statistical analysis}

The statistical analyses were carried out by using the Statistical Package for the Social Sciences (SPSS) 15.0 program. The larva to pupa and pupa to adult viability rates were compared by using a one-way ANOVA followed by the Games-Howell multiple comparison test. Statistical comparisons of developmental times were performed with a two-variable t-test. The ANOVA followed by LSD test analysis test was used for calculating the daily mean offspring number. The differences of daily mean egg production in each group were checked with ANOVA test by the Games-Howell multiple comparison test. The significance level for all statistical analyses was set at $\mathrm{p}<0.05$.

\section{Results}

\subsection{Effects of the MP on the pupation period}

The pupae that developed from larvae with and without MP were counted and viability rates of larva to pupa were determined. As a result of statistical analysis (ANOVA), it was seen that MP treatments were not effective on larva to pupa viability rates (Table 1 ).

Pupae were counted at 6-h intervals to determine the effect of MP on the developmental time of larva to pupa. It was determined that the mean larva to pupa developmental times were significantly prolonged in all MP treatment groups compared to control $(\mathrm{p}<0.05)$ (Table 2).

\subsection{Effects of the MP on the maturation period}

The pupa to adult viability rates of the control and MP treatment groups were determined and then compared 
using one-way ANOVA. Statistical analyses showed that MP treatments did not affect the pupa to adult viability rates (Table 3).

The developmental times of pupa to adult were also determined for all groups and were compared with a twovariable t-test. In the $50 \mathrm{mM} \mathrm{MP}$ group, the mean pupa to adult developmental time was significantly prolonged compared to the control $(\mathrm{p}<0.05)$. The mean pupa to adult developmental times of 100 and $200 \mathrm{mM}$ groups were longer than that of the control group. However, the differences were not significant (Table 4).

\subsection{Effects of the MP on daily mean offspring numbers}

To determine the effect of MP on the daily mean offspring number, offspring counting was performed for 10 days. As a result of the statistical analysis, it was determined that MP treatments did not cause significant changes in the mean number of offspring (Table 5).

\subsection{Effects of the MP on daily mean egg numbers}

The effects of MP on the fecundity of D. melanogaster were examined daily over a 10-day period. As seen in Table 6, all MP concentrations (50 mM, $100 \mathrm{mM}$, and $200 \mathrm{mM}$ ) reduced the daily mean egg productions significantly $(\mathrm{p}<0.05)$.

Table 1. Larva to pupa viability rates and significance levels of control and treatment groups

\begin{tabular}{cccc}
\hline Groups & Rate \pm S.E. & S.D. & $\mathrm{p}$ \\
\hline Control & $100 \pm 0.00$ & 0.000 & \\
$50 \mathrm{mM}$ & $98 \pm 0.01$ & 0.042 & \\
$100 \mathrm{mM}$ & $97 \pm 0.02$ & 0.048 & 0.288 \\
$200 \mathrm{mM}$ & $99 \pm 0.01$ & 0.032 & \\
\hline
\end{tabular}

S.E.: Standard error, S.D.: Standard deviation
Table 2. The effect of MP on larva to pupa developmental time

\begin{tabular}{cccc}
\hline Group No. & Groups & $\begin{array}{c}\text { Larva to Pupa } \\
\text { Developmental } \\
\text { Time }(\mathrm{h})\end{array}$ & $\begin{array}{c}\text { Significant Differences } \\
\text { of the Means } \\
\text { (p value) }\end{array}$ \\
\hline 1 & Control & 69.2 & \\
2 & $50 \mathrm{mM}$ & 71.7 & $1-2^{\star}(0.003)$ \\
3 & $100 \mathrm{mM}$ & 70.8 & $\left.1-3^{*} 0.028\right)$ \\
4 & $200 \mathrm{mM}$ & 70.4 & $1-4^{\star}(0.026)$ \\
\hline
\end{tabular}

*: Indicates significant delay in larva to pupa developmental time compared to control

Table 3. Pupa to adult viability rates and significance levels of control and treatment groups

\begin{tabular}{cccc}
\hline Groups & Rate \pm S.E. & S.D. & $p$ \\
\hline Control & $99 \pm 0.01$ & 0.032 & \\
$50 \mathrm{mM}$ & $99 \pm 0.02$ & 0.048 & \\
$100 \mathrm{mM}$ & $96 \pm 0.03$ & 0.083 & 0.163 \\
$200 \mathrm{mM}$ & $95 \pm 0.03$ & 0.090 & \\
\hline
\end{tabular}

S.E.: Standard error, S.D.: Standard deviation

Table 4. The effect of MP on mean pupa to adult developmental time

\begin{tabular}{cccc}
\hline Group No. & Groups & $\begin{array}{c}\text { Mean Pupa to Adult } \\
\text { Developmental } \\
\text { Time }(\mathrm{h})\end{array}$ & $\begin{array}{c}\text { Significant Differences } \\
\text { of the Means } \\
(\mathrm{p} \text { value })\end{array}$ \\
\hline 1 & Control & 70.5 & \\
2 & $50 \mathrm{mM}$ & 73.2 & $1-2^{*}(0.003)$ \\
3 & $100 \mathrm{mM}$ & 71.2 & \\
4 & $200 \mathrm{mM}$ & 72.3 & \\
\hline
\end{tabular}

*: Indicates significant delay in mean pupa to adult developmental time compared to control

Table 5. Effect of MP on daily mean offspring number of D. melanogaster

\begin{tabular}{cccccc}
\hline Group No. & Groups & No. of Female & No. of Offspring & $\begin{array}{c}\text { Daily Mean } \\
\text { Offspring Number } \pm \text { S.E. }\end{array}$ & $\begin{array}{c}\text { S.D. } \\
\text { of the Means }\end{array}$ \\
\hline 1 & Control & 22 & 2896 & $13.16 \pm 0.73$ & 10.828 \\
2 & $50 \mathrm{mM}$ & 24 & 3098 & $12.91 \pm 0.74$ & 11.428 \\
3 & $100 \mathrm{mM}$ & 25 & 3314 & $13.26 \pm 0.74$ & 11.642 \\
4 & $200 \mathrm{mM}$ & 25 & 3455 & $13.30 \pm 0.69$ & 10.967 \\
\hline
\end{tabular}

S.E.: Standard error, S.D.: Standard deviation

Table 6. Effect of MP on daily mean egg number of D. melanogaster

\begin{tabular}{|c|c|c|c|c|c|c|}
\hline Group No. & Groups & No. of Female & No. of Egg & $\begin{array}{c}\text { Daily Mean } \\
\text { Egg Number } \pm \text { S.E. }\end{array}$ & S.D. & $\begin{array}{l}\text { Significant Differences } \\
\text { of the Means ( } p \text { value) }\end{array}$ \\
\hline 1 & Control & 22 & 1560 & $7.09 \pm 0.56$ & 8.308 & \\
\hline 2 & $50 \mathrm{mM}$ & 23 & 1035 & $4.50 \pm 0.38$ & 5.735 & $1-2^{*}(0.001)$ \\
\hline 3 & $100 \mathrm{mM}$ & 23 & 911 & $3.96 \pm 0.38$ & 5.693 & $1-3^{*}(0.000)$ \\
\hline 4 & $200 \mathrm{mM}$ & 22 & 972 & $4.42 \pm 0.40$ & 5.979 & $1-4^{*}(0.001)$ \\
\hline
\end{tabular}

S.E.: Standard error, S.D.: Standard deviation

\section{Discussion}

Whether the additives used in the food, cosmetics, and pharmaceutical industries have a toxic effect is one of the most researched subjects. Considering the amount of substances added to foods and cosmetics and the number of people exposed to it, the importance of this issue is evident. For this reason, scientists are trying to determine the possible carcinogenic, mutagenic, and toxic effects of additives with in vivo and in vitro test methods. In this context, parabens are one of the most used and most studied chemical groups.

In this study, the effects of methylparaben (MP), one 
of the protective additives, on the developmental parameters and fecundity of Drosophila melanogaster were investigated. Although the effects of MP on larva to pupa and pupa to adult viability rates were not observed, MP treatments caused significant $(\mathrm{p}<0.05)$ delays in larva to pupa and pupa to adult developmental times. No significant change was observed in the daily mean number of offspring. However, daily average egg numbers were significantly decreased in the treatment groups compared to the control $(\mathrm{p}<0.05)$.

Many synthetic chemicals are known to mimic the effects of natural estrogens. These chemicals, defined as endocrine disruptors (EDCs), exert their effects by binding to estrogen receptors (Routledge et al., 1998). Parabens are also compounds that have the ability to bind to vertebrate estrogen receptors. Thus, they can act as EDCs (Vo et al., 2010).

Ecdysteroids are steroid hormones that play an important role in insects. 20-hydroxyecdysone (20E), an ecdysteroid hormone, exerts its effect by binding to ecdysone receptors. This hormone regulates developmental changes (such as metamorphosis) in fruit flies and other insects (Kozlova \& Thummel, 2000; Gáliková et al., 2011). The ecdysone receptor of $D$. melanogaster was determined to be homologous to the vertebrate estrogen receptor (Zou \& Fingerman, 1997). It is also noted that EDCs that can bind to steroid hormone receptors can also bind to ecdysteroid receptors of invertebrates (Watts et al., 2001). Liu et al. (2014) determined that EP treatments caused changes in ecdysone receptor gene $(E c R)$ and estrogen-related receptor gene (ERR) expression levels of D. melanogaster. Another study by Gao et al. (2020) found that EP increased EcR expression and decreased the amount of 20E. They stated the reason for this is that EP mimics the 20E and induces EcR expression. Based on these published studies and the results of this study, it can be said that the MP may have bound to EcR by mimicking the 20E; thus, preventing $20 \mathrm{E}$ from binding to its receptor, causing delays in developmental time.

Another striking effect of MP on D. melanogaster in the present study was on the mean egg number. It was significantly decreased in all treatment groups compared to the control. Fecundity of $D$. melanogaster can be affected by many internal (age, genetic factors, and etc.) and external (population density, nutrition, humidity, temperature, and etc.) factors (Ashburner et al., 2011). Stress is one of the external factors affecting fecundity. Studies have shown that EDCs induce oxidative stress by causing the formation of free radicals in cells (Roy et al., 1997; Obata \& Kubota, 2000; Herrero et al., 2015). It is determined that parabens cause the formation of reactive oxygen species (ROS) and; thus, induce oxidative stress (Pop et al., 2011; Samarasinghe et al., 2018). It is also determined that ecdysteroid hormones are also effective on fecundity. It was reported that any effect that will increase the amount of ecdysteroids will decrease egg production (Rauschenbach et al., 2000). In addition, the balance between $20 \mathrm{E}$ and juvenile hormone $(\mathrm{JH})$ is of great importance for the normal oogenesis process in Drosophila (Soller et al., 1999). A study by Gu et al. (2009) showed that $2 \% \mathrm{MP}$ reduced the number of eggs, but $0.02 \% \mathrm{MP}$ increased them. In a similar study, it was determined that
EP increased fertility at low concentrations $(0.02 \%)$, while it decreased fecundity at high concentrations $(0.10 \%$, $0.20 \%$ ) (Liu et al., 2014). Based on the results of the current study and previous studies, we can say that MP may have affected fecundity by imitating the ecdysone hormone and disrupting the balance between JH and ecdysone. The MP treatments in the present study also may have increased the amount of ecdysteroid hormones by causing oxidative stress in the cells and this may have decreased egg production.

The results of this study showed that MP did not affect the survival of $D$. melanogaster but prolonged development time and decreased egg production. It can be said by looking at the results of both this study and previous studies that parabens, which are widely used in the food, pharmaceutical, and cosmetic industries, have toxic effects. Especially considering their endocrine disrupting effects, the use of these chemicals should be kept under control.

Acknowledgements: The author thanks Nevşehir Hacı Bektaş Veli University Scientific Research Projects Coordination Unit [Grant number: NEÜBAP16F36] for financial support and Kurtuluş ATLI for laboratory assistance.

Ethics committee approval: Ethics committee approval is not required for this study.

Conflict of interest: The author declares that there is no conflict of interest.

\section{References}

Ashburner, M., Golic, K., \& Hawley, R.S. (2011). Drosophila a laboratory handbook. New York, Cold Harbor Spring Laboratory Press, 1440pp.

Ayar, A. \& Uysal, H. (2013). Genotoxic and safety assessment of 2 parabens in somatic cells of in vivo Drosophila melanogaster. Turkish Journal of Biology, 37, 683-688. https:// doi.org/10.3906/biy-1303-60

Boberg, J., Taxvig, C., Christiansen, S., \& Hass, U. (2010). Possible endocrine disrupting effects of parabens and their metabolites. Reproductive Toxicology (Elmsford, N.Y.), 30(2), 301-312. https://doi.org/10.1016/j.reprotox.2010.03.011

Chen, Q., Pan, C., Li, Y., Zhang, M., \& Gu, W. (2016). The Combined Effect of Methyl- and Ethyl-Paraben on Lifespan and Preadult Development Period of Drosophila melanogaster (Diptera: Drosophilidae). Journal of Insect Science, 16(1), 15. https:// doi.org/10.1093/jisesa/iev146

Gáliková, M., Klepsatel, P., Senti, G., \& Flatt, T. (2011). Steroid hormone regulation of $C$. elegans and Drosophila aging and life history. Experimental Gerontology, 46(2-3), 141-147. https://doi.org/10.1016/j.exger.2010.08.021

Gao, L., Li, Y., Xie, H., Wang, Y., Zhao, H., Zhang, M., \& Gu, W. (2020). Effect of ethylparaben on the growth and development of Drosophila melanogaster on preadult. Environmental Toxicology and Pharmacology, 80, 103495. https:// doi.org/10.1016/j.etap.2020.103495

Gomez, E., Pillon, A., Fenet, H., Rosain, D., Duchesne, M.J., Nicolas, J.C., Balaguer, P., \& Casellas, C. (2005). Estrogenic activity of cosmetic components in reporter cell lines: parabens, UV screens, and musks. Journal of Toxicology and Environmental Health Part A, 68(4), 239-251. https://doi.org/10.1080/15287390590895054

Gu, W., Xie, D.J., \& Hou, X.W. (2009). Toxicity and estrogen effects of methylparaben on Drosophila melanogaster. Food Science, 30(1), 252-254.

Herrero, Ó., Planelló, R., \& Morcillo, G. (2015). The plasticizer benzyl butyl phthalate (BBP) alters the ecdysone hormone pathway, the cellular response to stress, the energy metabolism, and several detoxication mechanisms in Chironomus riparius larvae. Chemosphere ,128, 266-277. https://doi.org/10.1016/j.chemosphere.2015.01.059

Kozlova, T., \& Thummel, C.S. (2000). Steroid regulation of postembryonic development and reproduction in Drosophila. Trends in Endocrinology and Metabolism: TEM, 11(7), 276-280. https://doi.org/10.1016/s10432760(00)00282-4

Li, Y., Hou, X., Zhang, M., \& Gu, W. (2015). Effects of propylparaben on fecundity and lifespan in Drosophila melanogaster. Toxicological $\mathcal{E}$ 
Environmental Chemistry, 96(7), 1064-1074.

https://doi.org/10.1080/02772248.2015.1005091

Liu, T., Li, Y., Zhao, X., Zhang, M., \& Gu, W. (2014). Ethylparaben affects lifespan, fecundity, and the expression levels of ERR, EcR and YPR in Drosophila melanogaster. Journal of Insect Physiology, 71, 1-7. https://doi.org/10.1016/j.jinsphys.2014.09.008

Obata, T., \& Kubota, S. (2000). Formation of hydroxyl radicals by environmental estrogen-like chemicals in rat striatum. Neuroscience Letters, 296(1), 41-44. https:// doi.org/10.1016/s0304-3940(00)01619-0

Pop, A., Kiss, B., Vlase, L., Pop, D.S., Iepure, R., Paltinean, R., \& Loghin, F. (2011). Study of oxidative stress induction after exposure to bisphenol $\mathrm{A}$ and methylparaben in rats. Farmacia, 59, 539-49. https://doi.org/10.1016/j.toxlet.2011.05.768

Rauschenbach, I.Y., Sukhanova, M.Z., Hirashima, A., Sutsugu, E., \& Kuano, E. (2000). Role of ecdysteroid system in the regulation of Drosophila reproduction under environmental stress. Doklady Biological Science, 375, 641-643. https://doi.org/10.1023/a:1026610425973

Riad, M.A., Abd-Rabo, M.M., Abd El Aziz, S.A., El Behairy, A.M., \& Badawy, M.M. (2018). Reproductive toxic impact of subchronic treatment with combined butylparaben and triclosan in weanling male rats. Journal of Biochemical and Molecular Toxicology, 32(3), e22037. https://doi.org/10.1002/jbt.22037

Roy, D., Palangat, M., Chen, C.W., Thomas, R.D., Colerangle, J., Atkinson, A., \& Yan, Z.J. (1997). Biochemical and molecular changes at the cellular level in response to exposure to environmental estrogen-like chemicals. Journal of Toxicology and Environmental Health, 50(1), 1-29. https://doi.org/10.1080/009841097160573

Routledge, E.J., Parker, J., Odum, J., Ashby, J., \& Sumpter, J.P. (1998). Some alkyl hydroxy benzoate preservatives (parabens) are estrogenic. Toxicology and Applied Pharmacology, 153(1), 12-19. https://doi.org/10.1006/taap.1998.8544

Samarasinghe, S., Krishnan, K., Naidu, R., Megharaj, M., Miller, K., Fraser, B., \& Aitken, R.J. (2018). Parabens generate reactive oxygen species in human spermatozoa. Andrology, 6(4), 532-541. https://doi.org/10.1111/andr.12499

Soller, M., Bownes, M., \& Kubli, E. (1999). Control of oocyte maturation in sexually mature Drosophila females. Developmental Biology, 208(2), 337351. https://doi.org/10.1006/dbio.1999.9210

Soni, M.G., Carabin, I.G., \& Burdock, G.A. (2005). Safety assessment of esters of p-hydroxybenzoic acid (parabens). Food and Chemical Toxicology, 43(7), 985-1015. https:// doi.org/10.1016/j.fct.2005.01.020

Tavares, R.S., Martins, F.C., Oliveira, P.J., Ramalho-Santos, J., \& Peixoto, F.P. (2009). Parabens in male infertility-is there a mitochondrial connection?. Reproductive Toxicology (Elmsford, N.Y.), 27(1), 1-7. https://doi.org/10.1016/j.reprotox.2008.10.002

Vo, T.T., Yoo, Y.M., Choi, K.C., \& Jeung, E.B. (2010). Potential estrogenic effect(s) of parabens at the prepubertal stage of a postnatal female rat model. Reproductive Toxicology (Elmsford, N.Y.), 29(3), 306-316. https://doi.org/10.1016/j.reprotox.2010.01.013

Watts, M.M., Pascoe, D., \& Carroll, K. (2001). Chronic exposure to 17 alphaethinylestradiol and bisphenol A-effects on development and reproduction in the freshwater invertebrate Chironomus riparius (Diptera: Chironomidae). Aquatic Toxicology, 55(1-2), 113-124. https://doi.org/10.1016/s0166-445x(01)00148-5

Zhang, Z., Sun, L., Hu, Y., Jiao, J., \& Hu, J. (2013). Inverse antagonist activities of parabens on human oestrogen-related receptor $Y(E R R Y)$ : in vitro and in silico studies. Toxicology and Applied Pharmacology, 270(1), 16-22. https://doi.org/10.1016/j.taap.2013.03.030

Zou, E., \& Fingerman, M. (1997). Effects of estrogenic xenobiotics on molting of the water flea, Daphnia magna. Ecotoxicology and $\begin{array}{llll}\text { Environmental Safety, } & 38(3), & 281-285 .\end{array}$ https://doi.org/10.1006/eesa.1997.1589 